\title{
Detection of Bacteria in Environmental Samples by Direct PCR Without DNA Extraction
}

\author{
BioTechniques 31:598-607 (September 2001)
}

\begin{abstract}
Kimberly A. Fode-Vaughan, Charles F. Wimpee, Charles C. Remsen, and Mary Lynne Perille Collins

University of Wisconsin-Milwaukee, Milwaukee, WI, USA
\end{abstract}

\section{INTRODUCTION}

Molecular techniques have become important tools in microbial ecology because of the limitations of culturebased analyses of microorganisms in environmental samples. It is well known that microorganisms cultured from environmental samples represent only a minor portion of the total microbial community. The use of molecular techniques allows the evaluation of the structure, dynamics, and metabolic potential of environmental samples, which is not possible to infer from data from the relatively few cultured organisms. However, the use of molecular techniques with environmental samples depends on the recovery and purity of the DNA. The approaches used in most molecular ecological studies involve the direct extraction of DNA from natural samples $(19,25,27,35)$ or the recovery of cells from samples, followed by DNA extraction $(5,11,24)$. However, DNA recovery and purity vary among these procedures. The contamination of DNA by substances of environmental origin that inhibit PCR has necessitated the use of extensive procedures to obtain DNA of adequate purity $(11,27$, 35). Several investigators found that even after elaborate purification steps, it was still necessary to dilute the DNA preparations to minimize the inhibitory effect of remaining contaminants on PCR $(35,41)$.

An alternative approach that may avoid some of the problems associated with DNA extraction is the use of environmental samples directly in the PCR without prior isolation of DNA or pretreatment of the sample. This approach has been used with intact cultured bacterial cells $(22,26,39)$, clinical specimens $(28,31,38,40)$, and animals (16). Direct PCR (DPCR) on environmental samples has had only limited success $(20,27)$, perhaps because optimal conditions were not identified. In situ PCR, in which the PCR products are detected in individual cells that have been fixed and permeabilized, is another approach used for the analysis of environmental samples $(4,23)$.

Most probable number (MPN)-PCR has been used by investigators to quantify organisms after the extraction of DNA $(7,41,46)$. This approach involves the serial dilution of DNA before PCR; quantitative estimates are based on the statistical analysis of replicate series in which the template is diluted to extinction. In the present study, MPN in conjunction with DPCR (MPN-DPCR) was applied to the detection of methanotrophic bacteria in environmental samples. These bacteria, which are widespread in the environment, use methane as the sole source of carbon and energy and can co-metabolize low molecular weight halogenated hydrocarbons, which are toxic pollutants $(8,30,32,33,49,53)$. Their role in the global carbon cycle and in bioremediation applications makes the detection 
and quantification of methanotrophs in the environment important.

Methane monooxygenase (MMO) oxidizes methane to methanol and can also oxidize a variety of substrates including ground water contaminants such as trichloroethylene (TCE). There are two distinct forms of MMO-a soluble MMO (sMMO) and a particulate MMO (pMMO). The pMMO (encoded by pmoCAB) has been found in all known methanotrophic bacteria with one possible exception (6), while the sMMO (encoded by the mmo gene cluster) is restricted to a subset of methanotrophs (36). Because pMMO is widespread in methanotrophs, it serves as a useful marker for the detection of these bacteria in the environment. This can apply to studies of microbial ecology and bioremediation. Effective bioremediation requires the monitoring of relevant bacterial populations over time and in response to the augmentation of the site.

The application of DPCR to the detection of bacteria in environmental samples is not limited to methanotrophs. Primers for the amplification of pufM were used to detect phototrophic bacteria, and primers for $16 \mathrm{~S}$ rDNA were used to detect members of the bacterial domain in natural samples.

\section{MATERIALS AND METHODS}

\section{Bacteria and Growth Conditions}

The methanotrophic bacteria Methylomicrobium album BG8, Methylosinus trichosporium $\mathrm{OB} 3 \mathrm{~b}$, Methylococcus capsulatus (Bath), Methylocystis parvus OBBP, and EPA (a landfill strain) (44) were grown as previously described (5). Photosynthetic bacteria were also grown as previously described (37). Cells were enumerated by direct count using a phase contrast microscope and a Petroff-Hauser counting chamber. Cultures were diluted to 2 $\times 10^{8}$ cells $/ \mathrm{mL} ; 50-\mu \mathrm{L}$ aliquots containing $10^{7}$ cells were stored at $-20^{\circ} \mathrm{C}$ for DPCR analysis.

\section{Environmental Samples}

Samples YS7, YS21, and YS27 were collected with a remotely operated vehicle (Eastern Oceanics, West
Redding, CT, USA) from hydrothermal vents in Yellowstone Lake as previously described (45). The Great Lakes Research Facility (GLRF) ground water has also been previously described (5). The MW-1 ground water sample was obtained from a TCE-contaminated site that was being monitored for natural attenuation (10). Filter-sterilized ground water was obtained by recovering the filtrate using $0.22-\mu \mathrm{m}$ filters. Sediment (GBsed) was the upper 1-2 cm subsample from a box core obtained from a station in Green Bay, Lake Michigan, adjacent to a site that has been previously described (3). Another sediment sample was from Lake 12, a eutrophic, marl hard water lake in Washington County, WI, USA. The peat was obtained from an acid bog at the University of Wisconsin-Milwaukee Field Station in Saukville, WI, USA. The peat and sediment were initially diluted to a ratio of 1:100 with deionized, UV-irradiated water before storage. Environmental samples were stored in aliquots of $50 \mu \mathrm{L}$ at $-20^{\circ} \mathrm{C}$ until they were used for DPCR analysis.

\section{Molecular Techniques}

Cultured methanotrophs were used to evaluate the DPCR method. A $50-\mu \mathrm{L}$ aliquot containing $10^{7}$ cells was thawed and decimally diluted with deionized, UV-irradiated water to a theoretical concentration of $1 \times 10^{-1}$ cells. Each dilution was used as a template in PCR. Serial dilution followed by PCR was performed in five replicate series for each bacterial strain. PCR amplifications were performed in $100-\mu \mathrm{L}$ volumes under a layer of mineral oil (Sigma, St. Louis, MO, USA) using a model 480 thermal cycler (Applied Biosystems, Foster City, CA, USA). Each PCR contained $200 \mu \mathrm{M}$ each dNTP, $1.5 \mathrm{mM}$ $\mathrm{MgCl}_{2}, 10 \mathrm{mM} \mathrm{NaCl}, 0.01 \mathrm{mM}$ EDTA, $0.1 \mathrm{mM}$ DTT, $5 \mathrm{mM}$ Tris-HCl, $\mathrm{pH}$ 8.0, $2 \%$ dimethyl sulfoxide, $5 \%$ glycerol, $0.1 \%$ Triton $^{\circledR} \mathrm{X}-100$, and $2.5 \mathrm{U}$ Taq DNA polymerase (Promega, Madison, WI, USA). Primers (Table 1) were used at a concentration of $0.1 \mu \mathrm{M}$. The $p m o A$ primers (5) have sequences that are present in 86 (64 are perfect matches and 22 have 1-3 mismatches) authentic pmoA sequences from cultured and uncultured methanotrophs that were de- posited in GenBank ${ }^{\circledR}$ by April 2001. This includes some organisms that are quite divergent on the basis of their $16 \mathrm{~S}$ or pmoA sequences $(1,19,25)$, suggesting that these primers may be useful in identifying uncultured methanotrophs in the environment. The primers for am plification of $16 \mathrm{~S}$ rDNA are modified from universal $16 \mathrm{~S}$ bacterial primers (51). The primer $907 \mathrm{GF}$ hybridizes to the sequence complementary to $926 \mathrm{R}$ and has five additional $G$ residues on the $5^{\prime}$ end. The primer $1407 \mathrm{GR}$ was modified from 1407R by the addition of four $\mathrm{G}$ residues at the $5^{\prime}$ end. The pufM primers anneal to the highly conserved regions of this gene that encode a protein of the photochemical reaction center of phototrophic bacteria.

The PCR conditions included hot start (47), touchdown (18), and prolonged annealing time in the early cycles. The touchdown involved a decrease of one degree every two cycles, followed by cycles with a constant annealing temperature. Table 1 shows the annealing times and temperatures. Following a 10 -min hot start at $95^{\circ} \mathrm{C}$, annealing times of $2 \mathrm{~min}$ were used for the first six cycles of the touchdown, followed by 1 -min annealing times. Denaturation was at $95^{\circ} \mathrm{C}$ and extension was for $1 \mathrm{~min}$ at $72^{\circ} \mathrm{C}$. For the final cycle, a 5-min extension time was used.

Precautions were taken throughout this work to avoid the introduction of contaminating DNA. These precautions included the use of a separate room and materials for all pre-amplification manipulations; this room was subjected to UV radiation when not in use. However, excessive high-dose UV exposure was avoided because this resulted in reduced PCR efficiency. This is probably attributable to the effect of UV on plastic, mineral oil, or other materials $(9,29)$. Control reactions without cells or DNA were used in all reaction series to ensure that contaminating template was not present. Amplified DNA (15 $\mu \mathrm{L}$ PCR) was analyzed on $1.5 \%$ agarose gels containing ethidium bromide. To confirm their identity, PCR products were sequenced by cycle sequencing with AmpliTaq $^{\circledR}$ DNA Polymerase FS using a model 373 DNA Sequencer (both from Applied Biosystems).

For environmental samples, a $50-\mu \mathrm{L}$ aliquot was thawed and serially diluted 


\section{Research Report}

Table 1. Primers and PCR Conditions Used for DPCR

\begin{tabular}{|c|c|c|c|c|c|c|}
\hline \multirow{2}{*}{$\frac{\text { Bacterial Group }}{\text { Detected }}$} & \multicolumn{2}{|c|}{ Target Product } & \multirow[b]{2}{*}{ Primer } & \multirow[b]{2}{*}{ Primer Sequence $\left(5^{\prime} \rightarrow 3^{\prime}\right)$} & \multicolumn{2}{|c|}{ Annealing Conditions } \\
\hline & Gene & Size (bp) & & & Touchdown & Constant \\
\hline \multirow[t]{2}{*}{ Methanotrophs } & $p m o A$ & $330 \mathrm{bp}$ & pmof1 & GGGGGAACTTCTGGGGITGGAC & $53^{\circ} \mathrm{C}-42^{\circ} \mathrm{C}$ & $45^{\circ} \mathrm{C}$ \\
\hline & & & pmor & GGGGGRCIACGTCITTACCGAA & 24 cycles & 20 cycles \\
\hline \multirow[t]{2}{*}{ Bacteria } & $16 S$ & 509 bp & 907GF & GGGGGAAACTYAAAKGAATTGACGG & $65^{\circ} \mathrm{C}-51^{\circ} \mathrm{C}$ & - \\
\hline & & & 1407GR & GGGGGACGGGCGGTGTGTRC & 30 cycles & \\
\hline \multirow[t]{2}{*}{ phototrophs } & pufM & 191 bp & pufmf & CGGCAACCTGTTCTACAACCCGTTCCA & $65^{\circ} \mathrm{C}-51^{\circ} \mathrm{C}$ & $55^{\circ} \mathrm{C}$ \\
\hline & & & pufmr & CCCATCGTCCAGCGCCAGAA & 30 cycles & 10 cycles \\
\hline
\end{tabular}

to a ratio of 1:10 with deionized, UV-irradiated water using $50-\mu \mathrm{L}$ volumes. Each dilution was used as a template in PCR. This was performed in five replicate reaction series. The PCR conditions were as described above.

\section{MPN-DPCR}

The MPN and confidence limits were calculated using a Microsoft ${ }^{\circledR}$ Excel $^{\circledR}$ computer program developed by Briones et al. (2) to apply the algorithm of Halvorson et al. (17). To test the method, the MPN was determined by DPCR on methanotroph lab strains diluted to extinction in five replicate series. To determine the number of cells in the sample, the three critical dilutions around the endpoint were entered into the program as positive or negative reactions. A sample calculation is shown in Table 2; see Briones et al. (2) for detailed information. The MPN determined was divided by two because two copies of the $p m o A$ have been identified in methanotrophs $(15,48)$. A preliminary report of this work has been presented (14).

\section{RESULTS AND DISCUSSION}

The DPCR method was first applied to laboratory strains to optimize a protocol (Table 1) to maximize sensitivity with the pmoA primers. Suspensions of cells $\left(10^{7}\right.$ cells $)$ were decimally diluted to extinction, and the detection limit was determined as the lowest number of cells that, when used as a template, yielded a PCR product that could be detected on an agarose gel. For $M$. albumBG8 and M. capsulatus (Bath), 10 cells could consistently be detected (data not shown). When purified M. albumBG8 DNA was used as a template, the detection limit was 10 genome equivalents (data not shown). For $M$. trichosporium $\mathrm{OB} 3 \mathrm{~b}$ and $M$. parvus OBBP, 10-100 cells were required for detection and for EPA, 100-1000 cells were required (data not shown). The detection limit determined with the $p m o A$ primers using the five strains of methanotrophs demonstrates that the sensitivity, to some extent, is cell specific. This differing sensitivity could reflect differences in the susceptibility of the cells to lyse under the hot-start conditions of the PCR, factors affecting the binding of the primers with the particular templates, and/or PCR efficiency, including differences in sequence, genome size, and copy number of the target gene $(13,42,50)$.

To apply statistical analysis to the determination of bacterial numbers by dilution to extinction, MPN-DPCR was used to quantify the number of methanotrophic cells, using the results of the five replicate dilution series of each methanotroph strain. The number of cells in the original sample was determined by MPN-DPCR and compared to the direct count (Table 3). For M. albumBG8 and M. capsulatus (Bath), the direct count was eight times greater than the MPN (Table 3). This is consistent with the observation that the detection limit for these strains is approximately 10 cells. In contrast, the MPN determinations for $M$. trichosporium OB3b, $M$. parvus OBBP, and EPA are a greater underestimate of bacterial number (Table 3).

Before the application of this method to environmental samples, initial experiments were performed with seeded samples to determine if constituents in the sample would affect the sensitivity of the method. M. album

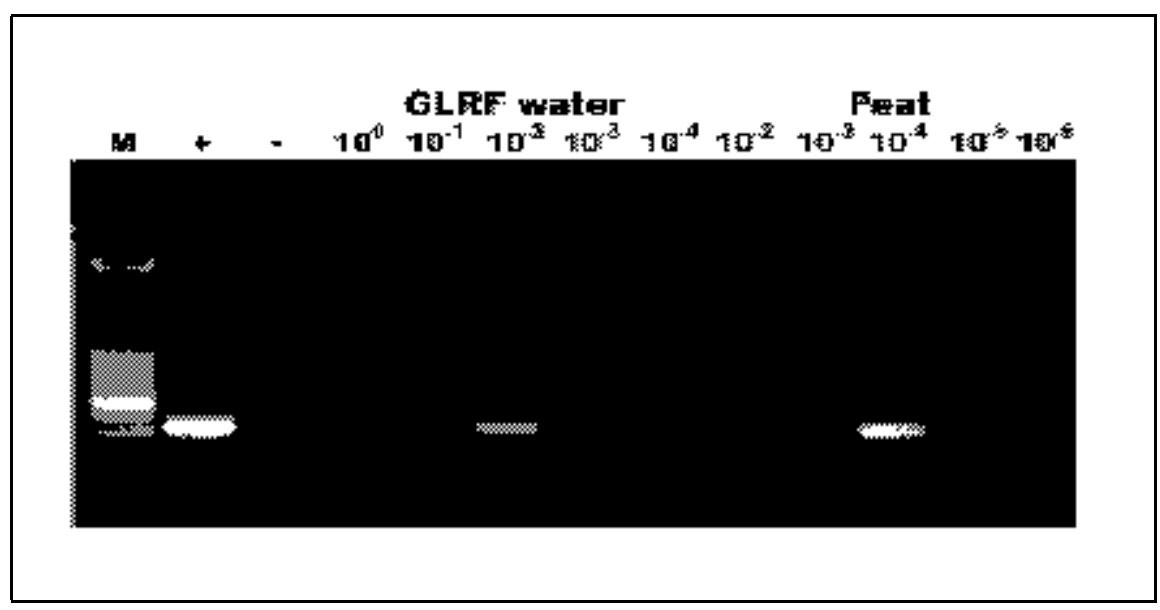

Figure 1. PCR with serial dilutions of environmental samples. Primers used were pmof1 and pmor. M, 100-bp ladder (Promega); +, positive control, M. albumBG8 DNA; -, negative control, no DNA; dilutions of GLRF water and peat. 
Table 2. Sample Calculation of MPN

\begin{tabular}{|c|c|c|c|c|c|c|}
\hline Sample & Dilution & $\begin{array}{l}\text { No. } \\
\text { Positive }\end{array}$ & $\begin{array}{l}\text { No. } \\
\text { Negative }\end{array}$ & $\begin{array}{l}\text { No. of } \\
\text { Samples }\end{array}$ & $\begin{array}{l}\text { Fraction of } \\
\text { mL Analyzeda }\end{array}$ & MPND \\
\hline \multirow[t]{3}{*}{ BG8 } & $10^{-5}$ & 5 & 0 & 5 & 0.05 & \multirow[t]{3}{*}{$4.8 \times 10^{7}$} \\
\hline & $10^{-6}$ & 5 & 0 & 5 & 0.005 & \\
\hline & $10^{-7}$ & 0 & 5 & 5 & 0.0005 & \\
\hline \multicolumn{7}{|c|}{$\begin{array}{l}\text { aFraction of the original sample }(0.05 \mathrm{~mL}) \text { and relative quantities that were } \\
\text { analyzed. }\end{array}$} \\
\hline \multicolumn{7}{|c|}{$\begin{array}{l}\text { bConfidence limits are determined by multiplying or dividing the MPN by } 3.302 \\
\text { for the upper and lower limits, respectively. }\end{array}$} \\
\hline
\end{tabular}

Table 3. Comparison of the Number of Methanotrophs in a 1-mL Sample Determined by Direct Count and DPCR

\begin{tabular}{|llll|}
\hline Strain & $\begin{array}{c}\text { Direct } \\
\text { Count }\end{array}$ & $\begin{array}{c}\text { MPN- } \\
\text { DPCP }\end{array}$ & $\begin{array}{c}\text { 95\% Confidence } \\
\text { Limits }\end{array}$ \\
\hline M. albumBG8 & $2 \times 10^{8}$ & $2.40 \times 10^{7}$ & $7.25 \times 10^{6}$ to $7.90 \times 10^{7}$ \\
M. capsulatus (Bath) & $2 \times 10^{8}$ & $2.40 \times 10^{7}$ & $7.25 \times 10^{6}$ to $7.90 \times 10^{7}$ \\
M. trichosporiumOB3b & $2 \times 10^{8}$ & $7.90 \times 10^{6}$ & $2.40 \times 10^{6}$ to $2.62 \times 10^{7}$ \\
M. parvus OBBP & $2 \times 108$ & $4.93 \times 10^{6}$ & $1.50 \times 10^{6}$ to $1.63 \times 10^{7}$ \\
EPA & $2 \times 10^{8}$ & $4.93 \times 10^{5}$ & $1.50 \times 10^{5}$ to $1.63 \times 10^{6}$ \\
aBecause the copy number of pmoA in these methanotrophs is or is assumed to \\
be two (15,48), the population estimated by MPN-PCR was divided by two. \\
\hline
\end{tabular}

BG8 cells serially diluted in filter-sterilized GLRF ground water or deionized water were used as templates for PCR. The endpoint (10 M. albumBG8 cells) was not affected by the presence of materials in filter-sterilized ground water (data not shown).

The PCR protocol was then applied to a variety of environmental samples. Figure 1 shows examples of the analyses of a ground water and peat sample. Neither undiluted nor $10^{-1}$ diluted GLRF ground water yielded a PCR product. A PCR product was obtained at the $10^{-2}$ and $10^{-3}$ dilutions of the GLRF water. The peat sample required a $10^{-4}$ dilution to overcome the effect of inhibitors on the PCR. The identity of these PCR products was confirmed by sequencing (data not shown). In each sample, a BLAST search revealed a predominant pmoA sequence significantly different from laboratory strains, indicating that the product generated from the environmental sample did not come from laboratory contamination.

For the purpose of quantifying methanotrophs in environmental samples, MPN-DPCR was determined using five replicate dilution series. Because methanotrophs may vary in the number of cells required to obtain a PCR product, quantification of methanotrophs in environmental samples cannot be made on an absolute basis but, rather, in comparison to a laboratory strain. For this purpose, the greatest dilution that was adequate as a template for the amplification of a $p m o A$ product was equated to $10 M$. album BG8 cells. This could be an underestimate of the methanotrophs present because of differences among the strains that may affect cell lysis or PCR efficiency. It is also possible that the methanotrophs in the environmental samples may differ in $p m o A$ copy number. Moreover, it is necessary to consider that, as with other molecular ecology methods, dead bacteria and/or free DNA in natural 


\section{Research Report}

Table 4. Quantification of Methanotrophs in Environmental Samples by MPN-DPCR

\begin{tabular}{|c|c|c|c|}
\hline Sample & $\begin{array}{l}\text { Greatest Dilution } \\
\text { Yielding PCR Producta }\end{array}$ & $\begin{array}{c}\text { No of } M \text {. album BG8 } \\
\text { Equivalents } / \mathrm{mL}\end{array}$ & 95\% Confidence Limits \\
\hline \multicolumn{4}{|c|}{ Ground Water } \\
\hline GLRF & $10^{-2}(3), 10^{-3}(2)$ & $4.93 \times 10^{4}$ & $1.50 \times 10^{4}$ to $1.63 \times 10^{5}$ \\
\hline$M W-1$ & $10^{-1}(2), 10^{-2}(3)$ & $7.90 \times 10^{3}$ & $2.40 \times 10^{3}$ to $2.62 \times 10^{4}$ \\
\hline \multicolumn{4}{|c|}{ Lake Waterb } \\
\hline YS7 & $10^{-1}(5)$ & $2.40 \times 10^{2}$ & $7.25 \times 10^{1}$ to $7.90 \times 10^{2}$ \\
\hline YS21 & $10^{-2}(5)$ & $2.40 \times 10^{3}$ & $7.25 \times 10^{2}$ to $7.90 \times 10^{3}$ \\
\hline YS27 & $10^{-2}(5)$ & $1.60 \times 10^{3}$ & $4.84 \times 10^{2}$ to $5.30 \times 10^{3}$ \\
\hline peat & $10^{-4}(1), 10^{-5}(4)$ & $1.30 \times 10^{7 c}$ & $3.94 \times 10^{6}$ to $4.29 \times 10^{7}$ \\
\hline GBsed & $10^{-4}(4), 10^{-5}(1)$ & $3.29 \times 10^{6 c}$ & $9.95 \times 10^{5}$ to $1.09 \times 10^{7}$ \\
\hline \multicolumn{4}{|c|}{$\begin{array}{l}\text { aNo. of replicates indicated by parentheses } \\
\text { bBacteria in samples were concentrated by centrifugation before analysis; calculation of the number of } M \text {. albumBG8 } \\
\text { equivalents reflects this concentration. }\end{array}$} \\
\hline \multicolumn{4}{|c|}{ cNo. of M. albumBG8 equivalents/g } \\
\hline
\end{tabular}

samples may be detected by PCR (12). Using this approach, methanotrophs were quantified as $M$. album BG8 equivalents in ground and lake waters, peat, and sediment (Table 4).

To evaluate the application of DPCR to the detection of other bacterial groups, two other primer pairs were tested. The specificity of the pufM primer pair was verified by PCR using Rhodospirillum rubrum, Rhodobacter capsulatus, Rhodobacter sphaeroides, and Rubrivax gelatinosus cells as templates. Based on sequence alignment, these primers are expected to amplify a pufM product from other phototrophic bacteria including Chromatium vinosum, Roseobacter denitrificans, Erythrobacter, and Blastochloris sulfoviridis. PCR with the pufM primers amplified a single product of the expected size with the Lake 12 sediment (data not shown). A product of the expected size was obtained with the $16 \mathrm{~S}$ primers using GLRF ground water as template (data not shown). For the $16 \mathrm{~S}$ amplification, the number of cycles was limited to 30 (Table 1); additional cycles resulted in a product in the noDNA control. This product is probably attributable to DNA contaminating the Taq DNA polymerase, as has been observed by others (21). With the appropriate primer design and PCR condi- tions, DPCR should be applicable to many bacterial groups, including those relevant to bioremediation and pathogens.

Successful DPCR requires primers and PCR conditions that maximize sensitivity. Optimization of conditions is important for PCR and especially critical for DPCR. If the detection limit is not sufficiently low, then the amount of template will be insufficient for detection in diluted samples. This is illustrated by comparing sensitivity of the detection of $M$. trichosporium $\mathrm{OB} 3 \mathrm{~b}$ cells with primers for $p m o A$ and $\operatorname{mmoX}(34)$; the latter encodes a protein of the sMMO. While 10-100 cells were sufficient to serve as a template for the former, $10^{4}$ cells were required for the latter under all of the conditions tested (data not shown). While the $m m o X$ primers were adequate for the amplification of a DNA template extracted from ground water (5), this primer pair could not be used to obtain a product by DPCR of such samples (unpublished data). It is possible that the greater sensitivity of PCR with the $p m o A$ primers compared to the mmoX primers is attributable to a greater tendency of the latter to form primer-dimers and hairpins. These nonproductive interactions would compete for template binding, particularly at low template concentra- tions. Another feature incorporated in primers used in this work is a 4- to $5-\mathrm{G}$ nucleotide extension at the $5^{\prime}$ end because preliminary experiments suggested that these additional nucleotides increased yield. While these extensions will not anneal to the template in the initial cycle, they will be incorporated into the product that serves as a template in subsequent cycles, thus stabilizing the priming event. Alternatively, $\mathrm{C}$ nucleotides may be used to avoid the potential interaction among adjacent $G$ nucleotides (43).

In addition to primer design, PCR conditions must be optimized for successful DPCR. Touchdown PCR uses a range of annealing temperatures. This may be particularly advantageous for environmental samples in which the sequences of templates present in the sample are unknown. Therefore, a melting temperature for primer/template binding cannot be calculated. Touchdown is suggested to compensate for suboptimal annealing temperatures and buffer conditions, including $\mathrm{Mg}^{2+}$ concentration (18). Extended annealing time in the early cycles is intended to compensate for differences in template density, which would be important in dilute samples. By increasing the annealing time in the first six PCR cycles, the detection limit for M. trichosporium 
OB3b with the $p m o A$ primers was improved (data not shown). Finally, the sensitivity can be increased by a large number of cycles. However, for tem plates that may be present as contaminants of the Taq DNA polymerase, such as $16 \mathrm{~S}$ rDNA, the sensitivity must be sufficient for DPCR, yet not so sensitive that contaminating DNA is amplified.

Because template integrity is essential to PCR, precautions were taken to minimize the impact of degradation. The samples were rapidly aliquoted in $50-\mu \mathrm{L}$ volumes, stored frozen, and thawed im mediately before dilution and DPCR. In addition, primers were chosen that required a small $(\leq 500 \mathrm{bp})$ template.

Because of its speed, simplicity, and ability to detect bacteria directly with minimal sample manipulation, DPCR is a useful approach for the detection and quantification of bacteria in environmental samples. However, this method has its limitations. The most important factor that determines the amount of DNA available is cell lysis efficiency (35). While this method may only be applicable for those cells that would lyse after being frozen once then heat-treated for $10 \mathrm{~min}$ (the PCR hot start), it is possible that modifications to this method may allow for the detection of other cell types. Another limitation of DPCR is that the least abundant bacteria will not be present in the most dilute samples.

The method chosen for the study of bacteria in environmental samples is dictated by experimental goals, the nature of the sample, and the bacterial group being assessed. It has been suggested that, ideally, multiple methods should be used for the detection of organisms to avoid a potentially biased view of the community of organisms that may occur when a single method is used (52). While the use of DPCR is limited to those samples that have a sufficiently high concentration of methanotrophs (or other target groups) to withstand the dilution necessary to eliminate the effect of inhibitors, a diverse array of environments tested meet this criterion, suggesting that this method should be widely applicable. We suggest that DPCR is a useful tool for some applications and may be used in conjunction with other methods for the analysis of microbes in the environment.
In conclusion, DPCR is a simple and rapid method that may be used qualitatively to detect the presence of a particular target group in natural samples. DPCR may also be used quantitatively to assess changes in the magnitude of the target group over time or in response to changes in the environment. DPCR may be used in conjunction with MPN analysis as described here or in competitive PCR (unpublished data). The detection and quantification of methanotrophs at TCE-contaminated sites being assessed for natural attenuation (Table 4, MW-1) suggest that this method will be suitable for monitoring bioremediation. DPCR may also be used preparatively to obtain PCR products for cloning, sequencing, or other analytical techniques. Such techniques could allow qualitative assessment of the microbial community diversity.

\section{ACKNOWLEDGMENTS}

This work was supported with funds from the University of Wisconsin Water Resources Center and the Wisconsin Department of Natural Resources. The samples from Yellowstone Lake were obtained in a field study supported by grant no. NOAA NA76RU0060 to J. Maki and grant no. NSF EAR9708501 to R. Cuhel. We thank J. Drought for samples, P. Dunn for advice on statistics, and D. Saffarini and J. Maki for careful reading of the manuscript.

\section{REFERENCES}

1.Bodrossy, L., K.L. Kovács, I.R. McDonald, and J.C. Murrell. 1999. A novel thermophilic methane-oxidizing $\gamma$-proteobacterium. FEMS Microbiol. Lett. 170:335-341.

2.Briones, A.M. and W. Reichardt. 1999. Estimating microbial population counts by "most probable number" using Microsoft Excel. J. Microbiol. Methods 35:157-161.

3.Buchholz, L.A., J.V. Klump, M.L.P. Collins, C.A. Brantner, and C.C. Remsen. 1995. Activity of methanotrophic bacteria in Green Bay sediments. FEMS Microbiol. Ecol. 16:18.

4.Chen, F., B. Binder, and R.E. Hodson. 2000. Flow cytometric detection of specific gene expression in prokaryotic cells using in situ RTPCR. FEMS Microbiol. Lett. 184:291-295.

5.Cheng, Y.S., J.L. Halsey, K.A. Fode, C.C. Remsen, and M.L.P. Collins. 1999. Detection of methanotrophs in groundwater by PCR. Appl. Environ. Microbiol. 65:648-651.
6.Dedysh, S.N., W. Liesack, V.N. Khmelenina, N.E. Suzina, Y.A. Trotsenko, J.D. Semrau, A.M. Bares, N.S. Panikov et al. 2000. Methylocella palustris gen. nov., sp. nov., a new methane-oxidizing acidophilic bacterium from peat bogs, representing a novel subtype of serine-pathway methanotrophs. Int. J. Syst. Evol. Microbiol. 50:955-969.

7.Degrange, V. and R. Bardin. 1995. Detection and counting of Nitrobacter populations in soil by PCR. Appl. Environ. Microbiol. 61:2093-2098.

8.DiSpirito, A.A., J. Gulledge, A.K. Shiemke, J.C. Murrell, M.E. Lidstrom, and C.L. Krema. 1992. Trichloroethylene oxidation by the membrane-associated methane monooxygenase in type I, type II, and type X methanotrophs. Biodegradation 2:151-164.

9.Dohner, D.E., M.S. Dehner, and L.D. Gelb. 1995. Inhibition of PCR by mineral oil exposed to UV irradiation for prolonged periods. BioTechniques 18:964-967.

10.Drought, J.F., E.A. Buc, T.J. Grundl, K.A. Fode, and M.L.P. Collins. 1999. Fate of tetrachloroethene and benzene at a dry cleaning facility, p. 253-258. In B.C. Alleman and A. Leeson (Eds.), Natural Attenuation of Chlorinated Solvents, Petroleum Hydrocarbons, and Other Organic Compounds. Battelle Press, Columbus, $\mathrm{OH}$.

11.Duarte, G.F., A.S. Rosado, L. Seldin, A.C. Keijzer-Wolters, J.D. van Elsas. 1998. Extraction of ribosomal RNA and genomic DNA from soil for studying the diversity of the indigenous bacterial community. J. Microbiol. Methods 32:21-29.

12.Dupray, E., M.P. Caprais, A. Derrien, and P. Fach. 1997. Salmonella DNA persistence in natural seawaters using PCR analysis. J. Appl. Microbiol. 82:507-510.

13.Farrelly, V., F.A. Rainey, and E. Stackebrandt. 1995. Effect of genome size and rrn gene copy number on PCR amplification of 16S rRNA genes from a mixture of bacterial species. Appl. Environ. Microbiol. 61:27982801.

14.Fode, K.A., C. Wimpee, C.C. Remsen, and M.L.P. Collins. 1999. Direct application of PCR to environmental samples, p. 572. Abstracts of the General Meeting of the American Society for Microbiology.

15.Gilbert, B., I.R. McDonald, R. Finch, G.P. Stafford, A.K. Nielsen, and J.C. Murrell. 2000. Molecular analysis of the pmo (particulate methane monooxygenase) operons from two type II methanotrophs. Appl. Environ. Microbiol. 66:966-975.

16.Grevelding, C.G., A. Kampkötter, M. Hollmann, U. Schäfer, and W. Kunz. 1996. Direct PCR on fruitflies and blood flukes without prior DNA isolation. Nucleic Acids Res. 24:4100-4101.

17.Halvorson, H.O. and N.R. Ziegler. 1933. Application of statistics to problems in bacteriology. Volume I. A means of determining bacterial populations by the dilution method. J. Bacteriol. 25:101-121.

18.Hecker, K.H. and K.H. Roux. 1996. High and low annealing temperatures increase both specificity and yield in touchdown and stepdown PCR. BioTechniques 20:478-485.

19.Henckel, T., U. Jäckel, S. Schnell, and R. 
Conrad. 2000. Molecular analyses of novel methanotrophic communities in forest soil that oxidize atmospheric methane. Appl. Environ. Microbiol. 66:1801-1808.

20.Herrick, J.B., E.L. Madsen, C.A. Batt, and W.C. Ghiorse. 1993. Polymerase chain reaction amplification of naphthalene-catabolic and 16S rRNA gene sequences from indigenous sediment bacteria. Appl. Environ. Microbiol. 59:687-694.

21.Hilali, F., P. Saulnier, E. Chachaty, and A. Andremont. 1997. Decontamination of polymerase chain reaction reagents for detection of low concentrations of 16S rRNA genes. Mol. Biotechnol. 7:207-216.

22.Hiraishi, A. 1992. Direct automated sequencing of $16 \mathrm{~S}$ rDNA amplified by polymerase chain reaction from bacterial cultures without DNA purification. Lett. Appl. Microbiol. 15:210-213

23.Hodson, R.E., W.A. Dustman, R.P. Garg, and M.A. Moran. 1995. In situ PCR for visualization of microscale distribution of specific genes and gene products in prokaryotic com munities. Appl. Environ. Microbiol. 61 :40744082.

24.Holben, W.E., J.K. Jansson, B.K. Chelm, and J.M. Tiedje. 1988. DNA probe method for the detection of specific microorganisms in the soil bacterial community. Appl. Environ. Microbiol. 54:703-711.

25.Holmes, A.J., P. Roslev, I.R. McDonald, N. Iversen, K. Henriksen, and J.C. Murrell. 1999. Chracterization of methanotrophic bacterial populations in soils showing atmospheric methane uptake. Appl. Environ. Microbiol. 65:3312-3318

26.Joshi, A.K., V. Baichwal, and G. FerroLuzzi Ames. 1991. Rapid polymerase chain reaction amplification using intact bacterial cells. BioTechniques 10:42-44.

27.Khan, A.A., R.A. Jones, and C.E. Cerniglia. 1998. Rapid method for the detection of genetically engineered microorganisms by polymerase chain reaction from soil and sediments. J. Ind. Microbiol. Biotechnol. 20:90-94.

28.Lan, J., J.M. Walboomers, R. Roosendaal, G.J. Van Doornum, D.M. MacLaren, C.J. Meijer, and A.J. Van den Brule. 1993. Direct detection and genotyping of Chlamydia trachomatis in cervical scrapes by using polymerase chain reaction and restriction fragment length polymorphism analysis. J. Clin. Microbiol. 31:1060-1065.

29.Linquist, V., C.A. Stoddart, and J.M. McCune. 1998. UV irradiation of polystyrene pipets releases PCR inhibitors. BioTechniques 24:50-51.

30.Little, C.D., A.V. Palumbo, S.E. Herbes, M.E. Lidstrom, R.L. Tyndall, and P.J. Gilmer. 1988. Trichloroethylene biodegradation by a methane-oxidizing bacterium. Appl. Environ. Microbiol. 54:951-956.

31.Liu, Y.S., R.J.S. Thomas, and W.A. Phillips. 1995. Single-step direct PCR amplification from solid tissues. Nucleic Acids Res. 23:1640.

32.Lontoh, S. and J.D. Semrau. 1998. Methane and trichloroethylene degradation by Methylosinus trichosporium $\mathrm{OB} 3 \mathrm{~b}$ expressing particulate methane monooxygenase. Appl. Envi- ron. Microbiol. 64:1106-1114.

33.Lontoh, S., J.A. Zahn, A.A. DiSpirito, and J.D. Semrau. 2000. Identification of intermediates of in vivo trichloroethylene oxidation by the membrane-associated methane monooxygenase. FEMS Microbiol. Lett. 186:109-113.

34.McDonald, I.R., E.M. Kenna, and J.C. Murrell. 1995. Detection of methanotrophic bacteria in environmental samples with the PCR. Appl. Environ. Microbiol. 61:116-121.

35.Moré, M.I., J.B. Herrick, M.C. Silva, W.C. Ghiorse, and E.L. Madsen. 1994. Quantitative cell lysis of indigenous microorganisms and rapid extraction of microbial DNA from sediment. Appl. Environ. Microbiol. 60:15721580.

36.Murrell, J.C., I.R. McDonald, and B. Gilbert. 2000. Regulation of expression of methane monooxygenases by copper ions. Trends Microbiol. 8:221-225.

37.Myers, C.R. and M.L.P. Collins. 1987. Cellcycle-specific fluctuation in cytoplasmic membrane composition in aerobically grow ing Rhodospirillum rubrum J. Bacteriol. 169:5445-5451.

38.Nordvåg, B.-Y., G. Husby, M.R. El-Gewely. 1992. Direct PCR of washed blood cells. BioTechniques 12:490-492.

39. Ohno, K., M. Tanaka, H. Ino, H. Suzuki, M. Tashiro, T. Ibi, K. Sahashi, A. Takahashi et al. 1991. Direct DNA sequencing from colony: analysis of multiple deletions of mitochondrial genome. Biochem. Biophys. Acta 1090:9-16

40.Panaccio, M., M. Georgesz, C. Hollywell, and A. Lew. 1993. Direct PCR from solid tissues without DNA extraction. Nucleic Acids Res. 21:4656.

41.Picard, C., C. Ponsonnet, E. Paget, X. Nesme, and P. Simonet. 1992. Detection and enumeration of bacteria in soil by direct DNA extraction and polymerase chain reaction. Appl. Environ. Microbiol. 58:2717-2722.

42.Polz, M.F. and C. Cavanaugh. 1998. Bias in template-to-product ratios in multitemplate PCR. Appl. Environ. Microbiol. 64:37243730.

43.Poon, K. and R.B. Macgregor. 1998. Unusual behavior exhibited by multistranded guanine-rich DNA complexes. Biopolymers 45:427-434.

44.Putzer, K.P., L.A. Buchholz, M.E. Lidstrom, and C.C. Remsen. 1991. Separation of methanotrophic bacteria by using Percoll and its application to isolation of mixed and pure cultures. Appl. Environ. Microbiol. 57:3656-3659.

45.Remsen, C.C., J.V. Klump, J. Kaster, R. Paddock, P. Anderson, and J.S. Maki. 1990. Hydrothermal springs and gas fumaroles in Yellowstone Lake, Yellowstone National Park, Wyoming. Natl. Geog. Res. 6:509-515.

46. Rosado, A.S., L. Seldin, A.C. Wolters, and J.D. van Elsas. 1996. Quantitative 16S rDNA-targeted polymerase chain reaction and oligonucleotide hybridization for the detection of Paenibacillus azotofixans in soil and the wheat rhizosphere. FEMS Microbiol. Ecol. 19:153-164.

47.Schuchard, M., G. Sarkar, T. Ruesink, and T.C. Spelsberg. 1993. Two-step "hot" PCR amplification of GC-rich avian $c-m y c$ sequences. BioTechniques 14:390-394.

48.Semrau, J.D., A. Chistoserdov, J. Lebron, A. Costello, J. Davagnino, E. Kenna, A.J. Holmes, R. Finch et al. 1995. Particulate methane monooxygenase genes in methanotrophs. J. Bacteriol. 177:3071-3079.

49.Smith, K.S., A.M. Costello, and M.E. Lidstrom. 1997. Methane and trichloroethylene oxidation by an estuarine methanotroph, Methylobacter sp. strain BB5.1. Appl. Environ. Microbiol. 63:4617-4620.

50.Suzuki, M.T. and S.J. Giovannoni. 1996 Bias caused by template annealing in the am plification of mixtures of 16S rRNA genes by PCR. Appl. Environ. Microbiol. 62:625-630.

51. Van de Peer, Y., P. De Rijk, J. Wuyts, T. Winkelmans, R. De Wachter. 2000. The European small subunit ribosomal RNA database. Nucleic Acids Res. 28:175-176.

52. Van Elsas, J.D., G.F. Duarte, A.S. Rosado, and K. Smalla. 1998. Microbiological and molecular biological methods for monitoring microbial inoculants and their effects in the soil environment. J. Microbiol. Methods 32:133-154.

53.Zahn, J.A. and A.A. DiSpirito. 1996. Mem brane-associated methane monooxygenase from Methylococcus capsulatus (bath). J. Bacteriol. 178:1018-1029.

Received 11 December 2000; accepted 16 April 2001.

Address correspondence to:

Dr. Mary Lynne Perille Collins

Dept. of Biological Sciences

University of Wisconsin-Milwaukee

P.O. Box 413

Milwaukee, WI 53201, USA

e-mail:mlpcolli@uwm.edu
For reprints of this or any other article, contact Reprints@BioTechniques.com 